УДК 550.72:579.266(571.65/.66)

\author{
СОСТАВ КУЛЬТИВИРУЕМЫХ БАКТЕРИЙ РАЗЛИЧНЫХ \\ ФИЗИОЛОГИЧЕСКИХ ГРУПП И ИХ ЧИСЛЕННОСТЬ \\ В ТЕРМАЛЬНЫХ ИСТОЧНИКАХ ГОРЯЧАЯ СОПКА, КАМЧАТКА \\ ${ }^{1}$ Лебедева Е.Г., ${ }^{2}$ Харитонова Н.А., ${ }^{1}$ Брагин И.В., ${ }^{3}$ Челноков Г.А. \\ ${ }^{\prime}$ ФГБУН «Дальневосточный геологический институт ДВО РАН», Владивосток, \\ e-mail:microbiol@mail.ru; \\ ${ }^{2}$ ФББОУВБ «Московский государственный университет имени М.В. Ломоносова», Москва; \\ ${ }^{3}$ ФББУН «Геологический институт РАН», Москва
}

\begin{abstract}
Проведено исследование химического состава, а также распространения, структуры и количества разнообразных экофизиологических групп микроорганизмов, участвующих в биогеохимических превращениях различных элементов (таких как углерод, азот, сера, железо, марганец, кремний) в термальных источниках и микробных матах Горячая сопка, Камчатка. Установлено, что термальные источники являются теплыми $\left(34,5^{\circ} \mathrm{C}\right)$ слабощелочными водами и обладают невысокой минерализацией. В составе катионов и анионов преобладают натрий-, кальций-, кремний-, сульфат-, хлорит- и гидрокарбонат-ионы. В микробиоценозе термальных вод и микробных матов выявлены небольшой состав экофизиологических групп бактерий, их низкая численность и небольшое разнообразие, что связано с низкими концентрациями органического вещества. Отмечены более высокие количественные показатели микрофлоры различных экофизиологических групп в микробных матах. В структуре сообществ термальных вод преобладали гетеротрофные нитрифицирующие, сапрофитные и силикатные микроорганизмы, осуществляющие процессы окисления органических веществ, соединений азота до нитритов и нитратов и участвующие в растворении силикатных минералов. В микробных матах показано доминирование в составе сообществ сапрофитных гетеротрофных бактерий, осуществляющих окисление органических веществ, хемолитотрофных тионовых микроорганизмов, участвующих в геохимических процессах окисления сульфидов до сульфатов, и бактерий-аммонификаторов, утилизирующих органические вещества, обогащенные азотом. Также были многочисленны бактерии, окисляющие железо и марганец. Выявлено преобладание в изученных объектах грамположительных, образующих споры палочковидных бактерий, способных утилизировать разнообразные углеродные субстраты. Выявлено, что в термальных водах наибольшее распространение имели грамположительные палочки Bacillus sp. и Arthrobacter sp., в микробных матах обнаружены крупные и мелкие палочки Bacillus sp., Pseudomonas sp., Paenibacillus sp. Microbacterium sp. с различным устройством клеточной стенки. Выделенные изоляты перспективны в биотехнологии.
\end{abstract}

Ключевые слова: термальные воды, состав, физиологические группы, бактерии, биоразнообразие, численность, Горячая сопка, Камчатка

\title{
COMPOSITION OF CULTIVATED BACTERIA OF DIFFERENT PHYSIOLOGICAL GROUPS AND THEIR NUMBER IN THERMAL SOURCES GORYACHAYA SOPKA, KAMCHATKA
}

\author{
${ }^{1}$ Lebedeva E.G., ${ }^{2}$ Kharitonova N.A., ${ }^{1}$ Bragin I.V., ${ }^{3}$ Chelnokov G.A. \\ ${ }^{1}$ Far East geological Institute, FEB RAS, Vladivostok, e-mail: microbiol@mail.ru; \\ ${ }^{2}$ Moscow state University named after M.V. Lomonosov, Moscow; \\ ${ }^{3}$ Geological institute RAS, Moscow
}

The study of the chemical composition, as well as the distribution, structure and number of various ecophysiological groups of microorganisms involved in the biogeochemical transformations of various elements (carbon, nitrogen, sulfur, iron, manganese, silicon) in thermal springs and microbial mats Goryachaya Sopka, Kamchatka. It was found that thermal springs are warm $\left(34.5^{\circ} \mathrm{C}\right)$, slightly alkaline waters and have low mineralization. Sodium, calcium, silicon, sulfate, chlorite and bicarbonate ions predominate in the composition of cations and anions. In the microbiocenosis of thermal waters and microbial mats, a small composition of the ecophysiological groups of bacteria, their low abundance and low diversity, was revealed, which is associated with low concentrations of organic matter. Higher quantitative indicators of microflora of various ecophysiological groups in microbial mats were noted. The structure of thermal water communities was dominated by heterotrophic nitrifying, saprophytic, and silicate microorganisms that oxidize organic substances, nitrogen compounds to nitrites and nitrates and participate in the dissolution of silicate minerals. In microbial mats, the dominance in the composition of communities of saprophytic heterotrophic bacteria carrying out the oxidation of organic substances, chemolithotrophic thionic microorganisms participating in the geochemical processes of the oxidation of sulfides to sulfates and bacteriaammonifiers, utilizing organic substances enriched with nitrogen. Bacteria that oxidize iron and manganese were also abundant. The predominance of gram-positive, spore-forming rod-shaped bacteria capable of utilizing a variety of carbon substrates was revealed in the studied objects. It was found that gram-positive Bacillus sp. and Arthrobacter sp. were most common in thermal waters, and large and small Bacillus sp., Pseudomonas sp., Paenibacillus sp. and Microbacterium $s p$. with different cell wall structures were found in microbial mats. The isolated isolates are promising in biotechnology.

Keywords: thermal waters, composition, physiological groups, bacteria, biodiversity, abundance, Goryachaya Sopka, Kamchatka 
Камчатка - уникальный в масштабе Земли район проявления современного вулканизма. По количеству и разнообразию термальных источников Камчатка не сравнится ни с одной из крупных курортных зон России. «Известно, что термальные источники являются местами активной деятельности микроорганизмов, которые участвуют в продукции и деструкции органического вещества, трансформации газов, образовании биологически активных веществ». «Огромно их значение в создании лечебного фактора минеральных вод и в процессах самоочищения». «Микроорганизмы различных физиологических групп выступают в роли индикаторов состояния окружающей среды» $[1,2]$. «Микробные маты представляют собой автономные сообщества с тесным взаимодействием трофических групп, где присутствуют и продукционная ветвь углеродного цикла, осуществляемая фототрофными бактериями, и деструкционная ветвь, осуществляемая различными группами бактерий» [3]. «Исследование микробных сообществ, ассоциированных с высокотемпературными экологическими нишами, представляет интерес как для фундаментальной микробиологии, в том числе эволюционной, поскольку многие обитающие в этих условиях микроорганизмы относятся к эволюционно древним ветвям термофильных бактерий и архей, так и для решения биотехнологических задач». «Российскими микробиологами были получены приоритетные данные об активности и составе сообществ лито- и органотрофных термофильных бактерий и архей некоторых высокотермальных источников Камчатки» [4-6]. Основные микробиологические исследования выполнены в кальдере Вулкана Узон, на Восточном термальном поле, а изучение микроорганизмов в термальных источниках Горячая сопка практически не проводилось [7].

В связи с тем, что данные по составу микроорганизмов в термах Горячая сопка в литературе не представлены, целью работы было изучить распределение, состав и численность основных экофизиологических групп бактерий, участвующих в основных биогеохимических циклах элементов в термальных источниках Горячая сопка, Камчатка.

\section{Материалы и методы исследования}

Исследованию подвергались теплые воды источников и микробные сообщества, образованные по месту их излива. Микробные маты представляли собой тонкие волосообразные нити темно-зеленого цвета толщиной 0,5-1 см, которые были образованы в местах стекания подземных термальных источников. Термальные источники расположены в долине реки Паратунка на северовосточном склоне сопки Горячая на полуострове Камчатка (рис. 1). Температура воды в источниках и в месте отбора микробных матов составляла $34,5^{\circ} \mathrm{C}$.

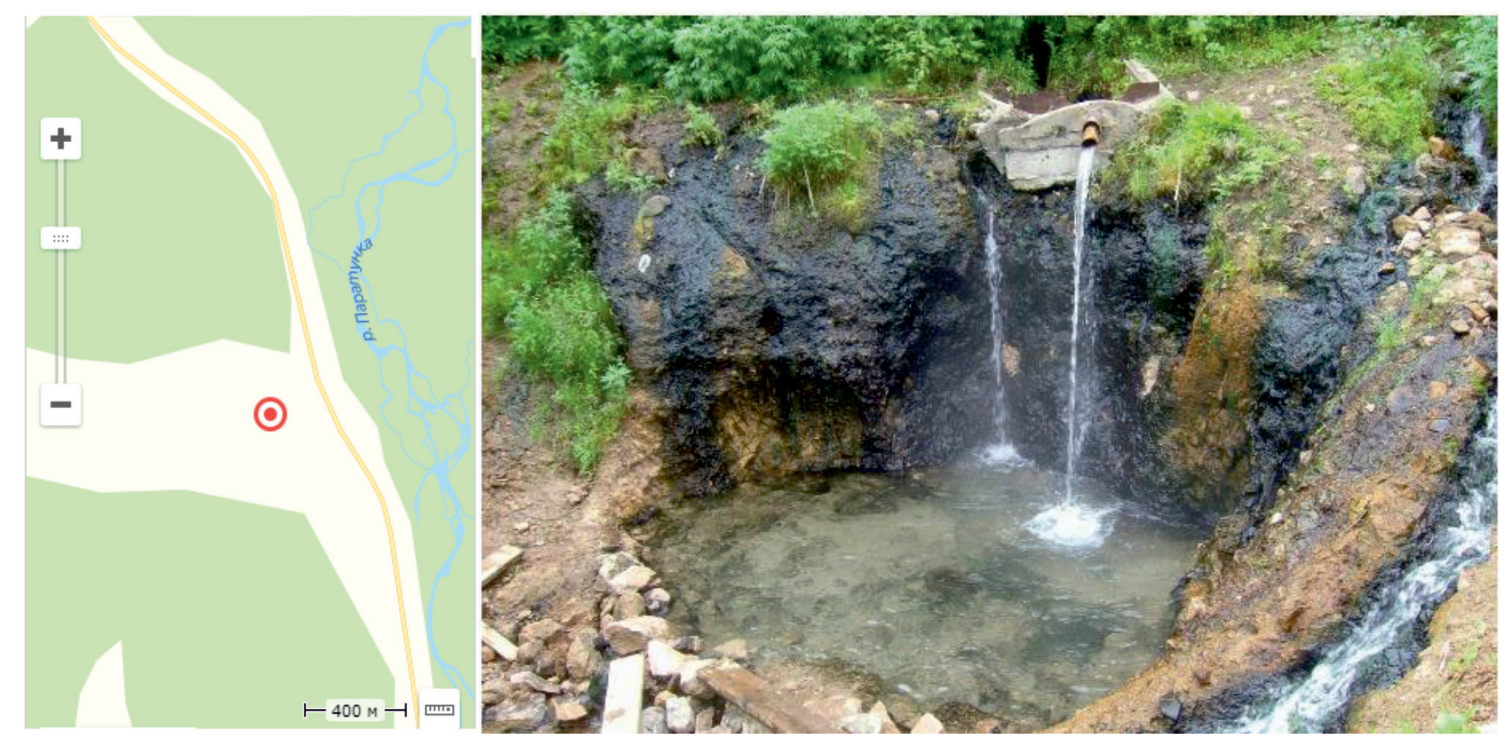

Рис. 1. Карта-схема расположения термальных источников Горячая сопка на полуострове Камчатка, Дальний Восток России 
Пробы термальных вод набирали стерильно из скважины в стеклянную стерильную тару таким образом, чтобы не оставалось пузырьков воздуха. Отбирали три бутылки по 500 мл с одного места. Сбор микробных матов производили стерильно в емкости из пластика (200 мл), затем заливали термальной водой и выдерживали в холодильнике не более 12 ч. Для изучения морфологии бактериальных матов использовали формалин для фиксации проб биоматериала. В микробных матах определяли только состав хемолитотрофных и гетеротрофных микробных сообществ. Пробы биоматериала (воды, биоматов) отбирали в сентябре 2015 г. Температуру, минерализацию, pH (химически нестойкие параметры) подземных вод измеряли при отборе биопроб с использованием портативных приборов. Анализ воды на катионы, анионы производили стандартными методами. Химический анализ образцов проведен в аналитическом центре Дальневосточного геологического института ДВО РАН. Выращивание и определение различных групп микроорганизмов производили с использованием методов классической микробиологии [8]. Количество экофизиологических групп микрофлоры учитывали методом Коха и предельных разведений [9]. Подсчет наиболее вероятной численности бактерий методом предельных разведений осуществляли по таблице Мак-Креди с составлением числовой характеристики. Использовали три повтора разведений. Подсчет колониеобразующих единиц (КОЕ) бактерий на твердых средах осуществляли в трех чашках Петри одного разведения, находя их среднее количество.

Число различных экофизиологических групп микробов выявляли на разнообразных селективных питательных средах [10], подобранных заранее. Количество азотфиксирующих микроорганизмов подсчитывали на элективной среде Эшби (г/л): маннит $-20, \mathrm{~K}_{2} \mathrm{HPO}_{4}-0,2, \mathrm{MgSO}_{4} \times 7 \mathrm{H}_{2} \mathrm{O}-0,2$, $\mathrm{NaCl}-0,2, \mathrm{~K}_{2} \mathrm{SO}_{4}-0,2, \mathrm{CaCO}_{3}-5,0$, дистиллированная вода - 1000 мл, агар-агар 15. Численность аммонифицирующих бактерий определяли на среде Зенгена, количество автотрофных нитрифицирующих бактерий устанавливали на средах Сориано и Уокера и Уотсона и Менделя, нитрифицирующих гетеротрофных бактерий выявляли на среде, содержащей (г/л): сухой питательный агар - 3,5, $\left(\mathrm{NH}_{2}\right) \mathrm{SO}_{4}-0,5$, вода дистиллированная - 1000 мл, агар-агар - 15 .
Численность микроорганизмов, способных к денитрификации, подсчитывали на элективной среде, разработанной Гильтаем (г/л): $\mathrm{KNO}_{3}-2,0$, аспарагин - 1,0, $\mathrm{KH}_{2} \mathrm{PO}_{4}-2,0$ г, $\mathrm{MgSO}_{4} \times 7 \mathrm{H}_{2} \mathrm{O}-2,0, \mathrm{CaCl}_{2}-0,2, \mathrm{FeCl}_{3}$ - следы, лимоннокислый натрий - 5,0 Г, агарагар - 15, дистиллированная вода - 1000 мл. Микроорганизмы, способные к сульфатредукции и хемолитотрофному восстановлению сульфидов (тионовые), учитывали на жидких средах Бейринка и Постгейта C с добавлением лактата натрия в качестве акцептора электронов. Количество бактерий, окисляющих железо и марганец гетеротрофно, устанавливали в соответствии с методикой по Крумбейн [10]. Численность автотрофных микроорганизмов, способных окислять железо, выявляли на элективной среде Летена, восстанавливающих железо и марганец гетеротрофных микробов учитывали на среде, разработанной Бромфильдом [8]. Количественное распространение сапрофитных микробов, растущих гетеротрофно, устанавливали на модифицированной среде Yochimizu, Kimura. Микрофлору, способную к росту только в анаэробных условиях, культивировали в специальных анаэробных контейнерах с созданием анаэробной атмосферы. Микроорганизмы выращивали в течение 5-14 суток в термостатах при температуре $34^{\circ} \mathrm{C}$. Особенности устройства клеточных стенок микробов выявляли с использованием метода Грама. Способность к образованию спор, морфологию колоний и клеток, их размеры, способность к движению изучали при помощи светового микроскопа AxioStar plus (Carl Zeiss, Германия). Определение гетеротрофных сапрофитных микробов до рода и изучение их свойств осуществляли по определителю бактерий Берджи.

\section{Результаты исследования и их обсуждение}

Исследование химического содержимого подземных вод выявило, что термы Горячая сопка относятся к теплым $\left(34,5^{\circ} \mathrm{C}\right)$, нейтральным ( $\mathrm{pH}=7,96)$, имеют невысокую минерализацию (650 мг/л) (табл. 1). Исследуемые термальные подземные воды являются кальциево-натриевыми, хлоридно-сульфатными, умеренно кремнистыми. В составе катионов термальных вод Горячая сопка отмечены повышенные концентрации натрия (105,0 мг/л), кальция (36,65 мг/л), кремния (21,71 мг/л). Содержание магния и калия низкое (табл. 1). Среди анионов в подземных водах преобладали сульфат- 
(236,0 мг/л), хлорит- (54,9 мг/л) и гидрокарбонат-ионы $(22,27$ мг/л). Концентрации брома и фтора низкие (табл. 1).

Согласно бактериологическим исследованиям, в теплых водах и микробных матах источника Горячая сопка обнаружены невысокий состав экофизиологических групп микробиоты (7-8 из 14) и их низкое количество (табл. 2). Аналогичные низкие концентрации бактерий и небольшой состав микрофлоры характерны для различных подземных вод Дальневосточного региона России $[11,12]$. Возможно, низкие концентрации органического вещества в термальных водах ограничивали рост численности бактерий. В подземных водах в структуре сообществ преобладали гетеротрофные нитрифицирующие $\left(1,3 \times 10^{3} \mathrm{KOE} / \mathrm{cm}^{3}\right)$, сапрофитные гетеро- трофные $\left(4,0-8,6 \times 10^{4} \mathrm{KOE} / \mathrm{cm}^{3}\right)$ и силикатные бактерии $\left(1,4 \times 10^{2} \mathrm{KOE} / \mathrm{cm}^{3}\right)$ (табл. 2$)$.

Присутствие данных физиологических групп в подземных водах свидетельствует об окислении ими органических и содержащих азот соединений до нитритов и нитратов, а также о растворении силикатных минералов при участии микрофлоры. Численность анаэробных форм сапрофитных бактерий немного превышала число аэробных, что свидетельствует о восстановительных условиях подземных вод (табл. 2). Сапрофитные бактерии формировали на среде YK преимущественно светло-бежевые, матовые, блестящие, а также молочного цвета колонии диаметром 2-6 мм. Преобладающее число бактерий являлись крупными грамположительными палочками различной длины (рис. 2).

Физико-химический состав терм Горячая сопка, Камчатка

Таблица 1

\begin{tabular}{|c|c|c|c|c|c|}
\hline \multicolumn{7}{|c|}{ Катионы, мг/л } \\
\hline $\mathrm{B}$ & $\mathrm{Ca}$ & $\mathrm{K}$ & $\mathrm{Mg}$ & $\mathrm{Na}$ & $\mathrm{Si}$ \\
\hline 2,55 & 36,65 & 1,60 & 0,37 & 105,0 & 21,71 \\
\hline \multicolumn{7}{|c|}{ Анионы, мг/л } \\
\hline $\mathrm{HCO}_{3}^{-}$ & $\mathrm{F}^{-}$ & $\mathrm{Cl}^{-}$ & $\mathrm{Br}$ & $\mathrm{NO}_{3}^{-}$ & $\mathrm{SO}_{4}{ }^{-2}$ \\
\hline 22,27 & 1,52 & 54,9 & 0,05 & 2,01 & 236,0 \\
\hline \multicolumn{2}{|c|}{ Температура, ${ }^{\circ} \mathrm{CH}$} & \multicolumn{2}{c|}{ Минерализация } \\
\hline \multicolumn{2}{|c|}{7,96} \\
\hline
\end{tabular}

Таблица 2

Количественное распределение разнообразных экофизиологических групп микробиоты в термальных источниках Горячая сопка, Камчатка

\begin{tabular}{|c|c|c|}
\hline Экофизиологические группы: & Теплые воды & Микробный мат \\
\hline Аэробные сапрофитные гетеротрофы, КОЕ/см³ & $4,0 \times 10^{2}$ & $1,7 \times 10^{4}$ \\
\hline Анаэробные сапрофитные гетеротрофы, КОЕ/см³ & $8,6 \times 10^{2}$ & $7,4 \times 10^{4}$ \\
\hline Фиксирующие азот, КОЕ/см³ & 0 & 0 \\
\hline Аммонифицирующие, КОЕ/см³ & 0 & $1,0 \times 10^{3}$ \\
\hline Автотрофные нитрифицирующие & 0 & 0 \\
\hline Гетеротрофные нитрифицирующие, КОЕ/см³ & $1,3 \times 10^{3}$ & 0 \\
\hline Осуществляющие денитрификацию & 0 & 0 \\
\hline 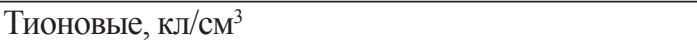 & $0,4 \times 10^{2}$ & $6,3 \times 10^{3}$ \\
\hline Сульфатредуцирующие, кл/см³ & 0 & $2,9 \times 10^{2}$ \\
\hline Железоокисляющие, КОЕ/см ${ }^{3}$ & $0,1 \times 10^{1}$ & $3,4 \times 10^{2}$ \\
\hline Марганецокисляющие, КОЕ/см³ & $0,9 \times 10^{1}$ & $4,7 \times 10^{2}$ \\
\hline Железовосстанавливающие, КОЕ/см ${ }^{3}$ & 0 & 0 \\
\hline Марганецвосстанавливающие, КОЕ/см ${ }^{3}$ & 0 & 0 \\
\hline Силикатные бактерии, КОЕ/см³ & $1,4 \times 10^{2}$ & $2,8 \times 10^{2}$ \\
\hline
\end{tabular}




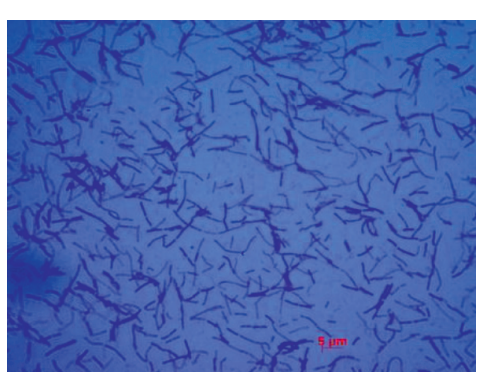

a)

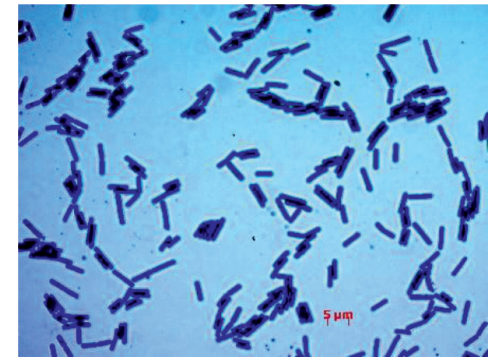

б)

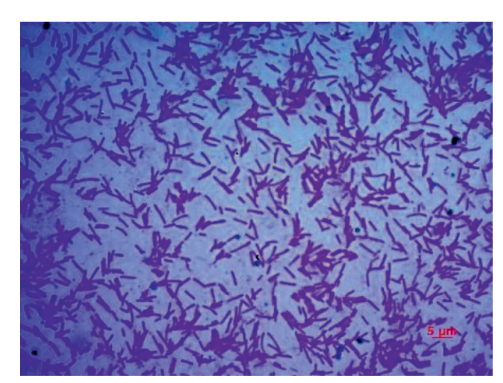

в)

Рис. 2. Морфология клеток гетеротрофных сапрофитов изолированных теплых источников Горячая сопка, Камчатка ( $а$ - бактерии из подземных вод, б, в - из микробных матов)

Численность гетеротрофных и хемолитотрофных бактерий в микробных матах была выше, чем в подземных водах, в среднем на два порядка, но не достигала высоких значений (табл. 2). В микробных матах по численности преобладали сапрофитные аэробные и анаэробные гетеротрофные бактерии $\left(1,7-7,4 \times 10^{4} \mathrm{KOE} / \mathrm{cm}^{3}\right)$, тионовые $\left(6,3 \times 10^{3}\right.$ кл/ $\left.\mathrm{cm}^{3}\right)$, аммонифицирующие $\left(1,0 \times 10^{3} \mathrm{KOE} / \mathrm{cm}^{3}\right)$, железо- и марганецокисляющие $\left(3,4-4,7 \times 10^{3} \mathrm{KOE} / \mathrm{cm}^{3}\right)$, сульфатредуцирующие $\left(2,9 \times 10^{2}\right.$ кл/см $\left.{ }^{3}\right)$ и силикатные микроорганизмы $\left(2,8 \times 10^{2} \mathrm{KOE} / \mathrm{cm}^{3}\right)$, что свидетельствует об участии микроорганизмов в биогеохимических циклах углерода, серы, железа, марганца, кремния. В геохимических превращениях углерода отмечено доминирующее участие гетеротрофных сапрофитов, проявляющих анаэробный рост, что говорит об окислении органических соединений. В цикле серы численность хемолитотрофных тионовых бактерий в микробных матах преобладала и составляла $6,3 \times 10^{3}$ кл/ $\mathrm{cm}^{3}$. «Известно, что тионовые бактерии являются хемолитоавтотрофами и способны в аэробных условиях окислять восстановленные соединения серы до сульфатов». «Тионовые бактерии в результате своей жизнедеятельности, вероятно, способствуют образованию сульфатов», концентрации которых довольно высоки в термальных источниках Горячая сопка и составляют 236,0 мг/л. Количество анаэробных сульфатредуцирующих бактерий, производящих восстановление сульфатов до сероводорода, было невысоко и составляло $2,9 \times 10^{2}$ кл/ $\mathrm{cm}^{3}$. Возможно, более низкие количества сульфатредуцирующих бактерий в матах можно объяснить низкой концентрацией органических веществ, необходимых для их развития, и насыщением матов кислородом, который подавлял развитие анаэробных микроорганизмов. Присутствие аммонифицирующих бактерий в структуре микробиоценоза свидетельствует о том, что микроорганизмы в матах осуществляют разложение азотсодержащих органических соединений (белков, аминокислот) путем ферментативного гидролиза с образованием аммиака, сероводорода и других соединений. Также в микробных матах отмечено небольшое количество марганеци железоокисляющих бактерий (табл. 2), которые обладали способностью окислять элементы. Железо- и марганецокисляющие микробы на элективных средах образовывали различного цвета колонии (бежевые, коричневые блестящие) размером 1-4 мм. При окраске по Граму выяснилось, что клетки этих бактерий представлены, в основном, грамотрицательным типом клеточной стенки с размерами 0,7-3,8 мкм в длину. Также в матах отмечены силикатные бактерии в количестве $2,8 \times 10^{2} \mathrm{KOE} / \mathrm{cm}^{3}$, что указывает на способность микроорганизмов растворять силикатные минералы.

Микробные маты представляют собой бентосные, вертикально-слоистые и самоподдерживающиеся сообщества, которые развиваются на границе раздела жидкость твердое тело в различных средах. Кроме того, они состоят из различных функциональных групп микроорганизмов, которые взаимодействуют и обмениваются сигналами, встроенными в матрицу экзополисахаридов и питательных веществ, чтобы обеспечить больший поток ресурсов и энергии для выживания сообщества. «Микробные маты функционируют как консорциум, в котором взаимосвязаны биогеохимиче- 
ские циклы и биохимические процессы, и это тесное взаимодействие позволяет продуктам метаболизма одной группы быть доступными и использоваться другими микроорганизмами». «Формирование этих сложных сообществ осуществляется в процессе экологической сукцессии, в которой цианобактерии являются колонизирующими организмами и модификаторами микроокружения для более поздней колонизации более специализированных бактерий и с более высокими и специфическими экологическими требованиями». Оксигенные и аноксигенные фототрофные цианобактерии, составляющие обычно основу мата, являются первичными продуцентами органического вещества и внеклеточных полимеров, которые составляют основу микробной пищевой цепи. Это образованное органическое вещество становится доступным для использования гетеротрофными микроорганизмами. Поэтому становится понятным, почему численность гетеротрофных групп бактерий выше в микробных матах, чем в подземных водах. В темноте ц̧ианобактерии и водоросли вдыхают свои эндогенные запасы углерода, тем самым истощая кислородный мат. Эти организмы продолжают истощать свои запасы углерода в бескислородных условиях путем ферментации, что приводит к образованию низкомолекулярных органических кислот и спиртов. Эти продукты ферментации дополнительно окисляются сульфатредуцирующими бактериями, часто совместно с другими гетеротрофными микроорганизмами. Сульфатредуцирующие бактерии - важная группа микроорганизмов, способных окислять органические вещества и восстанавливать сульфаты до сульфидов, которые с участием хемолитотрофных тионовых бактерий снова окисляются до сульфатов [13]. Таким образом, хемолитотрофные тионовые, сульфатредуцирующие и гетеротрофные сапрофитные бактерии играют важную роль в биогеохимических циклах углерода и серы в микробных матах источника Горячая сопка, Камчатка.

Микроорганизмы, изолированные из исследуемых объектов, были по устройству клеточной стенки в основном грамположительными палочками, способными к образованию спор. Размеры клеток варьировали в пределах от 0,2 до 4,0 мкм в длину. Выделенные культуры гетеротрофных бактерий использовали в своем метаболизме широкий набор углеродных субстратов: окисляли арабинозу, мальтозу, галактозу, сахарозу, маннит, дульцит, фруктозу, маннозу, глюкозу, глицерин, крахмал, дрожжевой экстракт, пептон. Тесты на каталазу большинства культур положительные. На безазотистой среде Эшби выделенные культуры роста не проявляли. Идентификация выделенных культивируемых штаммов сапрофитных гетеротрофных бактерий показала, что в термах больше всего отмечено бактериальных культур, принадлежащих к роду Bacillus sp. и Arthrobacter sp., в микробных матах преобладали микроорганизмы рода Bacillus sp., Pseudomonas sp., Paenibacillus sp. Microbacterium sp. Известно, что бактерии рода $B a$ cillus sp. широко распространены в природе и выделяются из различных источников (таких как вода, почва, воздух, животные, человек), в том числе эти бактерии доминируют в структуре сообществ в термальных водах и микробных матах различных гидротерм [13, 14]. Микроорганизмы, такие как Arthrobacter sp., Pseudomonas sp., Paenibacillus sp., Microbacterium sp., согласно литературным данным [15], были обнаружены ранее в различных термальных источниках и микробных матах, так что можно сделать вывод, что они часто встречаются в этих экосистемах и являются их нормальными обитателями.

\section{Заключение}

В подземных водах и микробных матах термальных источников Горячая сопка (Камчатка) отмечены низкая численность и небольшой состав экофизиологических групп бактерий, что связано с низкими концентрациями органического углерода. В подземных водах преобладали гетеротрофные нитрифицирующие, сапрофитные и силикатные бактерии, в микробных матах доминировали сапрофитные, хемолитотрофные тионовые, аммонифицирующие, железо- и марганецокисляющие микроорганизмы, что указывает на участие микрофлоры в биогеохимических циклах углерода, азота, серы, железа, марганца, кремния. Установлена важная роль тионовых и сульфатредуцирующих бактерий в круговороте серы в микробных матах. В термальных водах и микробных матах преобладали грамположительные спорообразующие палочковидные формы бактерий, способные использовать в качестве источника углерода широкий спектр субстратов. В подземных термальных водах выделенные гетеротрофные бактерии преимущественно представлены микроорганизмами рода $B a$ cillus sp. и Arthrobacter sp. В микробных ма- 
тах преобладали бактерии рода Bacillus sp., Pseudomonas sp., Paenibacillus sp. Microbacterium sp. Выделенные изоляты перспективны в биотехнологии как источники ценных ферментов.

\section{Список литературы / References}

1. Бабасанова О.Б., Будугаева В.Г., Бархутова Д.Д., Намсараев Б.Б. Органотрофные бактерии гидротерм Байкальской рифтовой зоны и их функциональная роль в микробиологическом сообществе // Вестник Бурятского государственного университета. Биология. 2013. № 4. C. $150-153$.

Babasanova O.B., Budugaeva V.G., Barkhutova D.D., Namsaraev B.B. Organotrophic bacteria in the hydrothermal waters of the Baikal rift zone and their functional role in the microbiological community // Vestnik Buryatskogo gosudarstvennogo universiteta. Biologiya. 2013. No. 4. P. 150-153 (in Russian).

2. Radnagurueva A.A., Lavrentieva E.V., Budugaeva V.G, Barchutova D.D, Dunaevskii Ya.E., Namsaraev B.B. Organotrophic bacteria of the Baikal rift zone hot springs. Microbiology. 2016. No. 3. P. 367-378.

3. Kashkak E.S., Bel'kova N.L., Danilova E.V., Dagurova O.P., Namsaraev B.B., Gorlenko V.M. Phylogenetic and functional prokaryotic diversity in the Hoito-Gol mesotherma mineral springs (Eastern Sayan Mountains, Buryat repablic). Microbiology. 2016. No. 5. P. 592-603.

4. Gumerov V.M., Mardanov A.V., Beletsky A.V., Ravin N.V., Bonch-Osmolovskaya E.A. Molecular analysis of microbial diversity in the Zavarzin spring, Uzon caldera, Kamchatka. Microbiology. 2011. No. 2. P. 244-251.

5. Заварзин Г.А. Изучение микробного разнообразия в институте микробиологии им. С.Н. Виноградского // Микробиология. 2004. № 5. С. 598-612.

Zavarzin G.A. Study of microbial diversity at the Institute of Microbiology. S.N. Vinogradsky // Mikrobiologiya. 2004. No. 5. P. 598-612 (in Russian).

6. Дворянчикова Е.Н., Кизилова А.И., Кравченко Н.К. Гальченко В.Ф. Анализ микробных сообществ термальных источников района озера Фумарольное кальдеры вулкана Узон, Камчатка // Известия Самарского научного центра PAH. 2011. T. 13. C. 1418-1424.

Dvoryanchikova E.N., Kizilova A.I., Kravchenko N.K. Galchenko V.F. Analysis of microbial communities of therma springs in the area of Lake Fumarole caldera of Uzon volcano, Kamchatka // Izvestiya Samarskogo nauchnogo tsentra RAN. 2011. Vol. 13. P. 1418-1424 (in Russian)

7. Nikulina T.V., Kalitina E.G., Kharitonova N.A., Chelnokov G.A., Vakh E.A., Grishchenko O.V. Chapter 14. Diatoms from hot springs of the Kamchatka Peninsula (Russia). Diatoms:
Fundamentals \& Applications. J. Seckbach, R. Gordon (eds.). Wiley-Scrivener, Beverly, MA, USA. 2019. Vol. 1. P. 311-333. DOI: $10.1002 / 9781119370741 . c h 14$.

8. Лысак В.В., Желдакова Р.А., Фомина О.В. Микробиология, практикум. Минск: БГУ, 2015. 115 с.

Lysak V.V., Zheldakova R.A., Fomina O.V. Microbiology, practical. Minsk: BGU, 2015. 115 p. (in Russian).

9. Руководство к практическим занятиям по микробиологии / Под ред. Егорова Н.С. М.: Изд-во МГУ, 1995. 224 с.

Guide to practical classes in microbiology/ Pod red. Yegorova N.S. M.: Izd-vo MGU, 1995. 224 p. (in Russian).

10. Кузнецов С.И., Дубинина Г.А. Методы изучения водных микроорганизмов. М.: Наука, 1989. 228 с.

Kuznetsov S.I., Dubinina G.A. Methods for studying aquatic microorganisms. M.: Nauka, 1989. 228 p. (in Russian).

11. Калитина Е.Г., Харитонова Н.А., Вах Е.А. Распространение бактерий различных эколого-трофических групп в подземных термальных водах Кульдурского месторождения (Дальний Восток России) // Современные проблемы науки и образования. 2017. № 5. [Электронный ресурс]. URL: http://www.science-education.ru/ru/article/view?id=26940 (дата обращения: 21.11.2020).

Kalitina E.G., Kharitonova N.A., Vakh E.A. Distribution of bacteria of various ecological-trophic groups in the underground thermal waters of the Kuldur deposit (Far East of Russia) // Sovremennyye problemy nauki i obrazovaniya. 2017. No. 5. [Electronic resource]. URL: http:/www.science-education.ru/ru/article/ view?id=26940 (date of access: 21.11.2020) (in Russian).

12. Лебедева Е.Г., Харитонова Н.А., Челноков Г.А., Кузьмина Т.В. Структура, численность и состав физиологических групп бактерий в Карымшинских термальных источниках (Камчатка, дальний Восток) // Естественные и технические науки. 2020. № 9. С. 25-27.

Lebedeva E.G., Kharitonova N.A., Chelnokov G.A., Kuzmina T.V. The structure, number and composition of physiological groups of bacteria in the Karymshinsky thermal springs (Kamchatka, the Far East) // Yestestvennyye i tekhnicheskiye nauki. 2020. No. 9. P. 25-27.

13. Prieto-Barajas C.M., Valencia-Cantero E., Santoyo G. Microbial mat ecosystems: structure types, functional diversity and biotechnological application. Electronic journal of biotechnology. 2018. Vol. 31. P. 48-56.

14. Aanniz T., Ouadghiri M., Melloul M., Swings J., Elfahime E., Ibijbijem J., Ismaili M., Amar M. Thermophilic bacteria in Moroccan hot springs, salt marshes and desert soil. Brazilian journal of microbiology. 2015. No. 2. P. 443-453.

15. Jardiue J.L., Abia A.L., Mavumengwana V., UbombaJaswa E. Phylogenetic analysis and antimicrobial profiles of cultured emerging opportunistic pathogens (phyla actinobacteria and proteobacteria) identified in hot springs. Int. journal of Environ. Res. Public health. 2017. Vol. 31. P. 48-56. 